Published in final edited form as:

Clin Lab Med. 2010 March ; 30(1): 47-65. doi:10.1016/j.cll.2009.10.006.

\title{
West Nile Virus
}

\author{
Shannan L. Rossi, Ph.D [Postdoctoral Scholar], \\ Center for Vaccine Research and Department of Microbiology and Molecular Genetics, University \\ of Pittsburgh, Pittsburgh, Pennsylvania
}

Ted M. Ross, Ph,D. [Member, Center for Vaccine Research; Associate Professor], and Department of Microbiology and Genetics, University of Pittsburgh, Pittsburgh, Pennsylvania

Jared D. Evans, Ph.D. [Member, Center for Vaccine Research; Assistant Professor] Department of Microbiology and Molecular Genetics, University of Pittsburgh, Pittsburgh, Pennsylvania

\section{Overview}

Since its isolation in Uganda in 1937, West Nile virus (WNV) has been responsible for thousands of cases of morbidity and mortality in birds, horses, and humans. Historically, epidemics were localized to Europe, Africa, the Middle East, and parts of Asia, and primarily caused a mild febrile illness in humans. However, in the late 1990's, the virus became more virulent and expanded its geographical range to North America. In humans, the clinical presentation ranges from asymptomatic (approximately $80 \%$ of infections) to encephalitis/paralysis and death (less than $1 \%$ of infections). There is no FDA-licensed vaccine for human use, and the only recommended treatment is supportive care. Individuals that survive infection often have a long recovery period. This article will review the current literature summarizing the molecular virology, epidemiology, clinical manifestations, pathogenesis, diagnosis, treatment, immunology, and protective measures against WNV and WNV infections in humans.

\section{Keywords}

West Nile virus; flavivirus; infection; pathogenesis; diagnosis

\section{Virology and Molecular Biology of WNV}

West Nile virus is a positive-stranded RNA virus in the family Flaviviridae (genus Flavivirus), which includes other human pathogens such as dengue, yellow fever, and Japanese encephalitis viruses [1,2]. The virion consists of an envelope surrounding an icosahedral capsid of approximately $50 \mathrm{~nm}$ in size. The $\sim 11$ kilobase genome encodes a single open reading frame, which is flanked by $5^{\prime}$ and $3^{\prime}$ untranslated regions (UTR). The approximately 3000 amino acid

\footnotetext{
(c) 2009 Elsevier Inc. All rights reserved.

Corresponding author for proof and reprints: Jared D. Evans, Ph.D., Center for Vaccine Research and Department of Microbiology and Molecular Genetics, 3501 Fifth Avenue, Pittsburgh, PA 15261, Evansj2@cvr.pitt.edu, (412) 648-7400, (412) 624-4440.

Coauthor addresses: Shannan L. Rossi, Ph.D., Center for Vaccine Research and Department of Microbiology and Molecular Genetics, 3501 Fifth Avenue, Pittsburgh, PA 15261, srossi@ pitt.edu, (412) 383-9605, (412) 624-4440; Ted M. Ross, Ph.D., Center for Vaccine Research and Department of Microbiology and Molecular Genetics, 3501 Fifth Avenue, Pittsburgh, PA 15261, tmr15@ pitt.edu, (412) 648-8666, (412) 624-4440

Publisher's Disclaimer: This is a PDF file of an unedited manuscript that has been accepted for publication. As a service to our customers we are providing this early version of the manuscript. The manuscript will undergo copyediting, typesetting, and review of the resulting proof before it is published in its final citable form. Please note that during the production process errors may be discovered which could affect the content, and all legal disclaimers that apply to the journal pertain.
} 
polyprotein is cleaved into ten proteins by cellular and viral proteases (Figure 1). Three of these proteins are the structural components required for virion formation (capsid protein (C)) and assembly into viral particles (premembrane (prM) and envelope proteins (E)). The other seven viral proteins are nonstructural (NS) proteins (NS1, NS2A, NS2B, NS3, NS4A, NS4B and NS5) and are all necessary for genome replication. NS3 contains an ATP-dependent helicase, and in conjunction with the NS2B protein, a serine protease, which is required for virus polyprotein processing. NS5 is a methyltransferase and RNA-dependent RNA polymerase (NS5). The other NS proteins are small, generally hydrophobic proteins of disparate functions. NS1 is a secreted glycoprotein implicated in immune evasion [3]. NS2A plays a role in virus assembly as well as inhibiting IFN- $\beta$ promoter activation [4,5]. NS4A is responsible for a rapid expansion and modification of the endoplasmic reticulum (ER) that helps establish replication domains [5-8]. NS4B blocks the IFN response [9-12]. Importantly, all the NS proteins appear to be necessary for efficient replication [13].

The flavivirus life cycle consists of 4 principal stages: attachment/entry, translation, replication, and assembly/egress (reviewed in \{Clyde, 2006 \#103; Lindenbach, 2001 $\# 199$ \}).WNV enters cells via receptor-mediated endocytosis, and is transported into endosomes. The WNV receptor is unknown. A number of cell-surface proteins are potential WNV receptors (DC-SIGN, Integrin alpha-v beta-3) [14-16] and the receptor required for WNV binding and entry may vary by cell type. Acidification of the endosomal compartment causes a conformational change in the $\mathrm{E}$ protein, resulting in fusion of the viral and endosomal membranes and release of the virus nucleocapsid into the cytoplasm $[17,18]$. The viral RNA is translated and the polyprotein is processed. Genome replication is carried out in specific domains established by the viral proteins $[19,20]$. As stated above, viral proteins cause massive expansion and modification of the ER. Two domains are important replication and virus protein processing: vesicle packets (VP) and convoluted membranes (CM), respectively [20-25] (Figure 2). Following replication and translation, genomes are packaged into virions, which mature through the ER-Golgi secretion pathway [19,20,26,27]. Progeny viruses are released by exocytosis.

\section{Phylogeny}

The most current phylogenetic studies (based upon sequences of entire or partial genome sequences) indicate five lineages of WNV [28]. The virus that entered North America belongs to lineage I (clade Ia). This lineage also contains viruses found in Europe, the Middle East and Africa. The genome of Kunjin virus, the Australian strain of WNV, also groups within lineage I (clade Ib). Lineage II is comprised of WNV mainly of African origin. Although there are exceptions, in general, lineage I (clade Ia) viruses can cause severe human neurologic disease whereas lineage I (clade Ib), and lineage II viruses generally cause a mild, self-limiting disease. Relatively little is known about the viruses that comprise lineages III, IV and V.

\section{Epidemiology}

WNV is maintained in nature in a cycle between birds and mosquitoes (Figure 3). Although many different species of mosquito are capable of maintaining this cycle, the Culex species play the largest role in natural transmission (Figure 4). Not all infected mosquitoes preferentially feed upon birds, which can lead to other animals including humans becoming infected. Humans (and horses) are incidental or "dead-end" hosts in this cycle since the concentration of virus within the blood (viremia) is insufficient to infect a feeding naïve mosquito. Other natural modes of WNV transmission have been documented, but occur rarely. WNV transmission can occur between infected mother and newborn via the intrauterine route [29-31] or possibly by breast-feeding [32]. A recent study of pregnant women who became infected with WNV during the 2003-4 transmission in the United States suggested that adverse 
health side effects of the newborn infant due to WNV infection of the mother are rare, and those cases with infant illness/infection/mortality may be associated with WNV infection that occurred while the mother was infected within 1 month prepartem [33].

Within the human population, the virus can spread between individuals by more artificial means. In the early 2000's, patients that received tainted blood or organs from viremic donors become infected [34-37]. These events highlighted the need to safeguard blood and organ donations from potentially viremic yet healthy donors, and relatively few infections via this route of transmission were reported since 2004.

The epidemiology of WNV is continuously changing. The virus was initially isolated from a febrile woman in Uganda in 1937 [38]. Since that time, few outbreaks of WNV in human or horse populations were recorded until the beginning of the 1990s. When disease was observed in humans, symptoms were typically mild and neurologic complications were rare \{Murgue, 2001 \#750; Hayes, 2001 \#776 . Noteworthy exceptions during this time were outbreaks in Israel in the early 1950s and France in the 1960s, which were characterized by encephalitis in humans and horses. A series of outbreaks in the 1990s brought WNV into the spotlight; epidemics in Algeria, Morocco, Tunisia, Italy, France, Romania, Israel, and Russia were associated with uncharacteristically severe human disease, including neurologic complications and death [39,41-43]. In the summer of 1999, a cluster of patients with encephalitis in New York City signaled the entry of WNV into North America. The sequence of the New York 1999 strain of WNV is closest in identity to a viral isolate from Israel [44], but it is still a mystery how the virus traversed the Atlantic Ocean. In the past decade, there have been thousands of reported human cases of WNV disease (WN fever and WN encephalitis) accompanied by over a thousand deaths (Table 1). The geographic range of the virus currently extends north into Canada, west across all 48 contiguous states, and south into Mexico, the Caribbean, and Central and South America (Figure 5 and 6) \{Blitvich, 2008 \#876\}. Since 2007, in addition to ongoing circulation of WNV in the Western Hemisphere, there have been outbreaks or isolations of WNV in Volograd (Russia) \{Platonov, 2008 \#877\}, South Africa \{Venter, 2009\#878\}, Hungary \{Krisztalovics, $2008 \# 879\}$, Romania \{Popovici, $2008 \# 880\}$, and Italy \{Rossini, $2008 \# 881\}$ (Figure 5).

In 2008 alone, there were 1338 cases of WNV disease reported to the CDC and resulted in 43 deaths within the United States

(http://www.cdc.gov/ncidod/dvbid/westnile/surv\&controlCaseCount08_detailed.htm).

\section{Clinical presentation}

It is difficult to accurately predict the incubation period of WNV in humans (time from mosquito bite/infection to the presentation of symptoms), but it is $\sim 2-15$ days $[34,45]$. The majority (>80\%) of WNV infections are asymptomatic. Symptomatic infections are primarily a mild, self-limiting febrile illness. However, approximately $1 \%$ of infected persons develop neurologic infections and disease. Most symptomatic patients exhibit mild illness with fever, sometimes associated with headache, myalgias, nausea and vomiting, and chills [34,46-49]. Further, some patients briefly present papular rash on the arms, legs, or trunk. These symptoms follow relatively predictable pattern with illness generally lasting less than seven days. However, a number of patients experience severe fatigue and malaise during convalescence.

Approximately 5 percent of patients with symptomatic WNV infection develop neurologic disease. WNV neurologic symptoms include meningitis, encephalitis, and poliomyelitis-like disease, presented as acute flaccid paralysis [50]. WNV encephalitis and/or meningitis are characterized by rapid onset of headache, photophobia, back pain, confusion and continued fever. WNV poliomyelitis-like syndrome is characterized by acute onset of asymmetric weakness and absent reflexes without pain. Patients presenting with flaccid paralysis require 
further testing to determine nature and degree of disease. Diagnostic tests including cerebrospinal fluid (CSF) examination should be performed in order to differentiate WNV infection from stroke, myopathy, and Guillain-Barre Syndrome. Other clinical symptoms may include tremor, myoclonus, postural instability, bradykinesia, and signs of parkinsonism.

\section{Pathogenesis}

Understanding the full range of WNV pathogenesis in humans has been difficult, mainly due to the difference in virulence between WNV strains, the high prevalence of asymptomatic or sub-clinical infections, and the relative infrequency of laboratory-confirmed human infections. Little has been published about human infections with WNV of limited virulence. The vast majority of our current knowledge regarding WNV pathogenesis resulted from animal models (mostly rodent) infected under controlled conditions with a known amount of needle-inoculated virus, which may not accurately reflect the course of a natural infection in humans.

Nevertheless, many descriptive accounts have been documented following the course of infection in humans suffering from $\mathrm{WN}$ fever and WN encephalitis resulting from a virulent lineage I WNV infection.

WNV-infected mosquitoes transmit the virus to humans following a bloodmeal from the host. During this process, mosquito saliva contaminated with WNV is deposited in the blood and skin tissue. Virus contained within the skin is presumed to infect resident dendritic cells such as Langerhans cells (MHCII+/NLDC145+/E-cadherin+ cells), which then traffic to the draining lymph node [51,52]. Shortly thereafter, virus amplifies in the tissues and results in a transient, low-level viremia, lasting a few days, and typically wanes with the production of anti-WNV IgM antibodies [53]. Following viremia the virus infects multiple organs in the body of the host, including the spleen, liver, and kidneys. Interestingly, 8 days after onset of symptoms, WNV was detected in the urine (viruria) of a patient with encephalitis [54], which is consistent with animal (hamster) experiments demonstrating viruria [54] and the presence of viral infection in the kidneys [55,56].

Upon entering the CNS, WNV causes severe neurological disease. WNV may enter the brain though a combination of mechanisms that facilitates viral neuroinvasion, such as direct infection with or without a breakdown of the blood-brain barrier (BBB) and/or virus transport along peripheral neurons. High viremia may easily lead to an infection of the brain if the BBB is disrupted and high viremia is correlated with severity of infection in experimentally infected mice [57]. Viremia and high viral titers in the periphery alone do not predict neuroinvasion.

Host proteins such as Drak2 (death-associated protein-kinaserelated 2), ICAM-1 (intercellular adhesion molecule), MIP (macrophage migration inhibitory factor) and MMP-9 (matrix metaloproeinase 9) have all been implicated in altering BBB permeability during WNV infection [58-61]. The virus may pass into the CNS without disrupting the BBB [62]. The host's response to infection may also contribute to WNV pathogenesis. Studies from experimentally infected mice suggest that the innate immune sensing molecule Toll-like receptor 3 (TLR3) may play a role in WNV invasion of CNS [63], possibly by mediating the upregulation of TNF$\alpha$ (tumor necrosis factor alpha), thereby resulting in capillary leakage and increased BBB permeability [64]. The pro-inflammatory chemokines/cytokines MCP-5 (monocyte chemoattractant protein 5), MIF, (IP-10) interferon gamma-inducible protein 10, MIC (monokine induced by gamma interferon), IFN- $\gamma$ (interferon gamma) and TNF- $\alpha$ were all upregulated in the brains of experimentally infected mice, suggesting that the host immune response may be (at least partially) responsible for neurolgical symptoms of the disease [58, 65]. However, an increase in BBB leakage does not accurately predict WNV-induced mortality in hamsters, nor does lethal infection increase BBB permeability in all strains of mice [66]. WNV may enter the brain by directly infecting and retrograde spreading along neurons in the periphery [67]. Entering the brain via infected peripheral neurons is a likely entry route since 
the level of viremia is low and leakage into the CNS by a breakdown of the BBB is less likely compared to animals with a high titer of circulating WNV in the blood. The discrepancies observed regarding BBB compromise suggest that further research is required to determine the exact mechanism through which WNV enters the CNS.

\section{Diagnosis}

Diagnosis of WNV infection depends on a number of factors, including environmental conditions, behaviors, and clinical symptoms. Patient history will give crucial clues to diagnosis. For example, if a patient presents with clinical symptoms, including fever and headache, one must consider the distribution of WNV and its mosquito vector. Endemic areas must consider WNV infection, especially during the summer months. Further, the patient history should suggest exposure to mosquitoes through outdoor activities. An initial physical examination will confirm clinical symptoms of fever, headache, myalgia, or the more severe meningitis and flaccid paralysis. Also, the presence of mosquito bites on the skin will assist in diagnosis.

To confirm the initial diagnosis, specific laboratory tests must be ordered (Table 2). To date, the most consistent manner to verify WNV infection is serology [47,49]. WNV antigen specific enzyme-linked immunosorbent assay (ELISA) will confirm infection. Serological tests include acute or convalescent samples of serum or cerebrospinal fluid (CSF) to determine the WNVspecific antibody profile by ELISA. The best test involves IgM-specific ELISA (MAC-ELISA) in which serum is collected within 8 to 21 days after the appearance of clinical symptoms. This test is commercially available and relatively inexpensive [34]. Also, serology can be performed to analyze immune responses. The presence of reactive lymphocytes or monocytes in CSF samples is indicative of WNV neurologic infection. More dramatically, a massive influx of polymorphonuclear cells occurs. In patients with WNV neuroinvasion, $>40 \%$ of cells in the CSF are neutrophils [68]. Plaque reduction and neutralization tests (PRNT) allow for identification of virus specificity. Virology tests can directly confirm the presence of virus. Serum or CSF is collected and virus is amplified within permissive cells and sequenced. This test is time-consuming and expensive. Finally, molecular biology tools can be employed to confirm the presence of virus. The nucleic acid test (NAT) is a powerful tool to detect WNV genomes. Serum or CSF is collected during the initial phases of virus infection can be directly amplified, or used to detect viral RNA by quantitative reverse transcription polymerase chain reaction (Q-RT-PCR) with virus-specific primers.

Magnetic resonance (MR) imaging suggests abnormalities in the brain and meninges of WNVinfected patients presenting with CNS disease $[46,69,70]$ (Figure 7). The regions of the CNS most commonly affected are basal gangli, thalami, brain stem, ventral horns, and spinal cord. However, the majority of these studies were performed retrospectively. Thus, the results do not provide predictive capabilities to WNV infection.

\section{Differential diagnosis}

A number of diseases manifest as symptoms similar to West Nile virus, including the encephalitides viruses (such as JEV and Murray Valley encephalitis virus) and bacterial meningitis. Therefore, differential diagnosis is crucial to determining WNV infection. A differential diagnosis is required when a patient presents with unexplained febrile illness, encephalitis or extreme headache, or meningitis. Thus far, the only manner to differentiate between causes of encephalitis/meningitis is diagnostic and serological laboratory tests to identify the specific pathogen causing the symptoms. 


\section{Treatment and long-term outcomes}

Currently, patients infected with WNV have limited treatment options. The primary course of action is supportive care. There is no FDA-licensed vaccine to combat WN disease in humans, despite the research of many laboratories and institutions and vaccines available for use in horses.

Furthermore, there are no effective antiviral to combat WNV infection. Two classical antiviral compounds, interferon and ribavirin, showed promising results in vitro [71,72] but it is unclear if these compounds are effective in patients [73-77]. Passively transferring anti-WNV immunoglobulin has been shown to be effective in mouse and hamster models [78] and may be helpful in patients $[79,80]$.

Long-term complications ( 1 year or greater after infection) are common in patients recovering from WNV infection. The most common self-reported symptom is fatigue and weakness, although myalgia, arthralgia, headaches, and neurologic complications, such as altered mental depression, tremors and loss of memory and concentration are not uncommon [81]. There is also evidence from animal models $[55,82,83]$ and human autopsies $[84,85]$ that the virus may persist in some individuals, as measured by isolation of virus or viral genomes or antigen months after infection or symptom presentation. Experimentally infected hamsters show longterm neurological sequela, which appears to coincide with the presence of both viral antigen and genome within areas of the brain showing neuropathology [83]. Although the direct evidence of persistence in humans is limited at this time, many patients have long-lasting WNV-specific IgM titers in the serum and CNS, suggesting that persistent infections may be more common than previously indicated [86-88].

\section{Immunity}

Both the innate and adaptive immune responses mounted against WNV are critically important for controlling infection. Type I interferons (alpha and beta) are important for limiting virus levels, reducing neuronal death, and increasing survival [57]. The amount of interferon made by the host in response to infection appears to be (at least in part) dependent upon the strain and/or virulence of the virus; mice infected with lineage I WNV with attenuating mutations produce less type I IFN than mice infected with virulent lineage I WNV [89]. Furthermore, WNV strains that are more resistant to the affects of IFN (like some virulent lineage I viruses) are more virulent than IFN-sensitive stains (like lineage II strains) [90].

The adaptive immune response also plays a role in controlling infection. Studies using WNVinfected genetically engineered knockout mice indicate that both T- [91-96] and B- [97]cells are critical for controlling infection. CD8+ T-cell recruitment to the brain by neurons expressing CXCL10 and by CD40-CD40 ligand interactions help reduce the viral burden in the brain and increase survival in experimentally infected mice [94,98]. B-cells are activated within the lymph nodes of WNV-infected mice 48-72 hours after infection in an IFN $\alpha / \beta$ signaling dependent manner, and B-cells secreting WNV-specific IgM were detected on day 7 post infection [99]. IgM is critically important for the control of early WNV infection, and passive transfer of WNV-specific IgM could protect IgM-deficient mice from lethal WNV infection [100]. Approximately 3-4 days after WNV-specific IgM is detectable, anti-WNV IgG titers are measurable in patients [53]. IgG is the predominant antibody most likely confering long-term immunity against WNV re-infection. Although not enough data exists, immunity against WNV in convalescent patients is presumed to be life-long. 


\section{Vaccination}

Although no FDA-approved vaccine exists for human use, there are effective, licensed vaccines for the treatment of horses. The success has encouraged others to develop these and other strategies for human vaccines. Currently, there are a number of ongoing clinical trials.

There are several strategies being pursued for WNV vaccine development (Table 3). The first strategy is inoculation of multiple doses of inactivated virus [101,102]. Fort Dodge Animal Health developed this strategy by formalin inactivating whole virus. This formulation has been approved for horses. The second strategy involves the production of WNV antigens from a heterologous virus backbone. The vectors being used are canarypox (Recombitek ${ }^{\mathrm{TM}}$ ), Yellow fever virus (Chimerivax TM), and Dengue 4 (WNV-DEN4) [103-106]. The Recombitek ${ }^{\mathrm{TM}}$ vaccine has been licensed for use in horses. The third approach is DNA vaccination. WNV structural antigens (prM-E) are expressed from DNA plasmids [107]. The final strategy is inoculation with purified viral proteins [108-111]. These proteins can be produced in mammalian cell culture, bacteria, or yeast. Interestingly, a recent study by Seino, et al. compared the efficacy of three available vaccines [112]. Their study showed that horses vaccinated with the live, chimeric virus in the yellow fever or canarypox vectors had fewer clinical signs of WNV disease than animals receiving inactivated virus.

\section{Summary}

In summary, WNV infection is a serious threat to public health, especially to the immunocompromised and elderly. The virus is maintained in an enzootic cycle between mosquitoes and birds, with humans and other mammals as incidental hosts. Since its introduction to the Western hemisphere in 1999, WNV has spread across North and South America in fewer than 10 years. The majority of human infections are asymptomatic. However, clinical manifestations range from relatively mild febrile illness to very severe neurological sequelae, including acute flaccid paralysis and encephalitis. Currently, the virus is the most significant cause of viral encephalitis in the United States. Efficient diagnosis of WNV infection requires a detailed history, including potential exposure to contaminated mosquitoes, as well as sensitive serological and virology assays. Recent studies have shed light on virushost interactions, including pathogenesis and immune evasion. Lastly, there are no prophylactic or therapeutic measures that exist to combat the diseases caused by WNV infection, thus warranting future research.

\section{Acknowledgments}

This work was supported by T32 Grant \#AI060525-04 from the National Institute of Heath (SR), W81XWHBAA-06-1 and W81XWH-BAA-06-2 (TMR), and CVR Funds (JE).

\section{References}

1. Gould EA, Solomon T. Pathogenic flaviviruses. Lancet 2008;371(9611):500-9. [PubMed: 18262042]

2. Lindenbach, BD.; Rice, CM. Flaviviridae: the viruses and their replication. In: Knipe, HP., editor. Fields Virology. Lippincott, Williams, \& Wilkins; Philadelphia: 2001. p. 991-1041.DM

3. Schlesinger JJ. Flavivirus nonstructural protein NS1: complementary surprises. Proc Natl Acad Sci U S A 2006;103(50):18879-80. [PubMed: 17146046]

4. Leung JY, et al. Role of nonstructural protein NS2A in flavivirus assembly. J Virol 2008;82(10):473141. [PubMed: 18337583]

5. Mackenzie JM, et al. Subcellular localization and some biochemical properties of the flavivirus Kunjin nonstructural proteins NS2A and NS4A. Virology 1998;245(2):203-15. [PubMed: 9636360] 
6. Egloff MP, et al. An RNA cap (nucleoside-2'-O-)-methyltransferase in the flavivirus RNA polymerase NS5: crystal structure and functional characterization. Embo J 2002;21(11):2757-68. [PubMed: 12032088]

7. Khromykh AA, Kenney MT, Westaway EG. trans-Complementation of flavivirus RNA polymerase gene NS5 by using Kunjin virus replicon-expressing BHK cells. J Virol 1998;72(9):7270-9. [PubMed: 9696822]

8. Speight G, et al. Gene mapping and positive identification of the non-structural proteins NS2A, NS2B, NS3, NS4B and NS5 of the flavivirus Kunjin and their cleavage sites. J Gen Virol 1988;69(Pt 1):2334. [PubMed: 2826667]

9. Evans JD, Seeger C. Differential effects of mutations in NS4B on West Nile virus replication and inhibition of interferon signaling. J Virol 2007;81(21):11809-16. [PubMed: 17715229]

10. Liu WJ, et al. Inhibition of interferon signaling by the New York 99 strain and Kunjin subtype of West Nile virus involves blockage of STAT1 and STAT2 activation by nonstructural proteins. J Virol 2005;79(3):1934-42. [PubMed: 15650219]

11. Munoz-Jordan JL, et al. Inhibition of alpha/beta interferon signaling by the NS4B protein of flaviviruses. J Virol 2005;79(13):8004-13. [PubMed: 15956546]

12. Munoz-Jordan JL, et al. Inhibition of interferon signaling by dengue virus. Proc Natl Acad Sci U S A 2003;100(24):14333-8. [PubMed: 14612562]

13. Khromykh AA, Sedlak PL, Westaway EG. cis- and trans-acting elements in flavivirus RNA replication. J Virol 2000;74(7):3253-63. [PubMed: 10708442]

14. Chu JJ, Ng ML. Interaction of West Nile virus with alpha v beta 3 integrin mediates virus entry into cells. J Biol Chem 2004;279(52):54533-41. [PubMed: 15475343]

15. Chu JJ, Ng ML. Infectious entry of West Nile virus occurs through a clathrin-mediated endocytic pathway. J Virol 2004;78(19):10543-55. [PubMed: 15367621]

16. Medigeshi GR, et al. West Nile virus entry requires cholesterol-rich membrane microdomains and is independent of alphavbeta3 integrin. J Virol 2008;82(11):5212-9. [PubMed: 18385233]

17. Modis Y, et al. Structure of the dengue virus envelope protein after membrane fusion. Nature 2004;427 (6972):313-9. [PubMed: 14737159]

18. Mukhopadhyay S, Kuhn RJ, Rossmann MG. A structural perspective of the flavivirus life cycle. Nat Rev Microbiol 2005;3(1):13-22. [PubMed: 15608696]

19. Mackenzie JM, Westaway EG. Assembly and maturation of the flavivirus Kunjin virus appear to occur in the rough endoplasmic reticulum and along the secretory pathway, respectively. J Virol 2001;75(22):10787-99. [PubMed: 11602720]

20. Westaway EG, Ng ML. Replication of flaviviruses: separation of membrane translation sites of Kunjin virus proteins and of cell proteins. Virology 1980;106(1):107-22. [PubMed: 6251615]

21. Westaway EG, Mackenzie JM, Khromykh AA. Replication and gene function in Kunjin virus. Curr Top Microbiol Immunol 2002;267:323-51. [PubMed: 12082996]

22. Westaway EG, et al. Ultrastructure of Kunjin virus-infected cells: colocalization of NS1 and NS3 with double-stranded RNA, and of NS2B with NS3, in virus-induced membrane structures. J Virol 1997;71(9):6650-61. [PubMed: 9261387]

23. $\mathrm{Ng} \mathrm{ML}$, et al. Immunofluorescent sites in vero cells infected with the flavivirus Kunjin. Arch Virol 1983;78(3-4):177-90. [PubMed: 6318692]

24. Bartenschlager R, Miller S. Molecular aspects of Dengue virus replication. Future Microbiol 2008;3:155-65. [PubMed: 18366336]

25. Welsch $\mathrm{S}$, et al. Composition and three-dimensional architecture of the dengue virus replication and assembly sites. Cell Host Microbe 2009;5(4):365-75. [PubMed: 19380115]

26. Miyanari $\mathrm{Y}$, et al. The lipid droplet is an important organelle for hepatitis $\mathrm{C}$ virus production. Nat Cell Biol 2007;9(9):1089-97. [PubMed: 17721513]

27. Miyanari $Y$, et al. Hepatitis $\mathrm{C}$ virus non-structural proteins in the probable membranous compartment function in viral genome replication. J Biol Chem 2003;278(50):50301-8. [PubMed: 12963739]

28. Bondre VP, et al. West Nile virus isolates from India: evidence for a distinct genetic lineage. J Gen Virol 2007;88(Pt 3):875-84. [PubMed: 17325360] 
29. Intrauterine West Nile virus infection--New York, 2002. MMWR Morb Mortal Wkly Rep 2002;51 (50):1135-6. [PubMed: 12537289]

30. From the Centers for Disease Control and Prevention. Intrauterine West Nile virus infection--New York, 2002. JAMA 2003;289(3):295-6. [PubMed: 12532964]

31. Alpert SG, Fergerson J, Noel LP. Intrauterine West Nile virus: ocular and systemic findings. Am J Ophthalmol 2003;136(4):733-5. [PubMed: 14516816]

32. Hinckley AF, O'Leary DR, Hayes EB. Transmission of West Nile virus through human breast milk seems to be rare. Pediatrics 2007;119(3):e666-71. [PubMed: 17332186]

33. O'Leary DR, et al. Birth outcomes following West Nile Virus infection of pregnant women in the United States: 2003-2004. Pediatrics 2006;117(3):e537-45. [PubMed: 16510632]

34. Petersen LR, Marfin AA. West Nile virus: a primer for the clinician. Ann Intern Med 2002;137(3): 173-9. [PubMed: 12160365]

35. Iwamoto M, et al. Transmission of West Nile virus from an organ donor to four transplant recipients. N Engl J Med 2003;348(22):2196-203. [PubMed: 12773646]

36. Biggerstaff BJ, Petersen LR. Estimated risk of transmission of the West Nile virus through blood transfusion in the US, 2002. Transfusion 2003;43(8):1007-17. [PubMed: 12869104]

37. Detection of West Nile virus in blood donations--United States, 2003. MMWR Morb Mortal Wkly Rep 2003;52(32):769-72. [PubMed: 12917583]

38. Smithburn KC, Hughes TP, Burke AW, Paul JH. A neurotropic virus isolated from the blood of a native of Uganda. Am. J. Trop. Medicine 1940;20:471-492.

39. Murgue B, et al. West Nile in the Mediterranean basin: 1950-2000. Ann N Y Acad Sci 2001;951:11726. [PubMed: 11797769]

40. Hayes CG. West Nile virus: Uganda, 1937, to New York City, 1999. Ann N Y Acad Sci 2001;951:2537. [PubMed: 11797781]

41. Bin H, et al. West Nile fever in Israel 1999-2000: from geese to humans. Ann N Y Acad Sci 2001;951:127-42. [PubMed: 11797770]

42. Platonov AE, et al. Outbreak of West Nile virus infection, Volgograd Region, Russia, 1999. Emerg Infect Dis 2001;7(1):128-32. [PubMed: 11266303]

43. Tsai TF, et al. West Nile encephalitis epidemic in southeastern Romania. Lancet 1998;352(9130): 767-71. [PubMed: 9737281]

44. Lanciotti RS, et al. Origin of the West Nile virus responsible for an outbreak of encephalitis in the northeastern United States. Science 1999;286(5448):2333-7. [PubMed: 10600742]

45. Mostashari F, et al. Epidemic West Nile encephalitis, New York, 1999: results of a household-based seroepidemiological survey. Lancet 2001;358(9278):261-4. [PubMed: 11498211]

46. Brilla R, et al. Clinical and neuroradiologic features of 39 consecutive cases of West Nile Virus meningoencephalitis. J Neurol Sci 2004;220(1-2):37-40. [PubMed: 15140603]

47. Hayes EB, Sejvar JJ, Zaki SR, Lanciotti RS, Bode AV, Campbell GL. Virology, pathology, and clinical manifestations of West Nile virus disease. Emerg Infect Dis 2005;11(8):1174-9. [PubMed: 16102303]

48. Petersen LR, Roehrig JT, Hughes JM. West Nile virus encephalitis. N Engl J Med 2002;347(16): 1225-6. [PubMed: 12270973]

49. Tyler KL. West Nile virus infection in the United States. Arch Neurol 2004;61(8):1190-5. [PubMed: 15313835]

50. Campbell GL, et al. West Nile virus. Lancet Infect Dis 2002;2(9):519-29. [PubMed: 12206968]

51. Byrne S, Halliday GM, Johnston LJ, King NJ. Interleukin-1 beta but not tumor necrosis factor is involved in West Nile virus-induced Langerhans cell migration from the skin in C57BL/6 mice. J Invest Dermatol 2001;117(3):702-9. [PubMed: 11564180]

52. Johnston L, Halliday GM, King NJ. Langerhans cells migrate to local lymph nodes following cutaneous infection with an arbovirus. J Invest Dermatol 2000;114(3):560-8. [PubMed: 10692118]

53. Busch MP, et al. Virus and antibody dynamics in acute west nile virus infection. J Infect Dis 2008;198 (7):984-93. [PubMed: 18729783]

54. Tonry JH, et al. Persistent shedding of West Nile virus in urine of experimentally infected hamsters. Am J Trop Med Hyg 2005;72(3):320-4. [PubMed: 15772329] 
55. Tesh RB, et al. Persistent West Nile virus infection in the golden hamster: studies on its mechanism and possible implications for other flavivirus infections. J Infect Dis 2005;192(2):287-95. [PubMed: 15962223]

56. Ding X, et al. Nucleotide and amino acid changes in West Nile virus strains exhibiting renal tropism in hamsters. Am J Trop Med Hyg 2005;73(4):803-7. [PubMed: 16222029]

57. Samuel MA, Diamond MS. Alpha/beta interferon protects against lethal West Nile virus infection by restricting cellular tropism and enhancing neuronal survival. J Virol 2005;79(21):13350-61. [PubMed: 16227257]

58. Arjona A, et al. Abrogation of macrophage migration inhibitory factor decreases West Nile virus lethality by limiting viral neuroinvasion. J Clin Invest 2007;117(10):3059-66. [PubMed: 17909632]

59. Dai J, et al. Icam-1 participates in the entry of west nile virus into the central nervous system. J Virol 2008;82(8):4164-8. [PubMed: 18256150]

60. Wang P, et al. Matrix metalloproteinase 9 facilitates West Nile virus entry into the brain. J Virol 2008;82(18):8978-85. [PubMed: 18632868]

61. Wang S, et al. Drak2 contributes to West Nile virus entry into the brain and lethal encephalitis. J Immunol 2008;181(3):2084-91. [PubMed: 18641347]

62. Verma S, et al. West Nile virus infection modulates human brain microvascular endothelial cells tight junction proteins and cell adhesion molecules: Transmigration across the in vitro blood-brain barrier. Virology 2009;385(2):425-33. [PubMed: 19135695]

63. Wang T, Town T, Alexopoulou L, Anderson JF, Fikrig E, Flavell RA. Toll-like receptor 3 mediates West Nile virus entry into the brain causing lethal encephalitis. Nat Med 2004;10(12):1366-73. [PubMed: 15558055]

64. Diamond MS, Klein RS. West Nile virus: crossing the blood-brain barrier. Nat Med 2004;10(12): 1294-5. [PubMed: 15580248]

65. Garcia-Tapia D, et al. West Nile virus encephalitis: sequential histopathological and immunological events in a murine model of infection. J Neurovirol 2007;13(2):130-8. [PubMed: 17505981]

66. Morrey JD, et al. Increased blood-brain barrier permeability is not a primary determinant for lethality of West Nile virus infection in rodents. J Gen Virol 2008;89(Pt 2):467-73. [PubMed: 18198377]

67. Samuel MA, et al. Axonal transport mediates West Nile virus entry into the central nervous system and induces acute flaccid paralysis. Proc Natl Acad Sci U S A 2007;104(43):17140-5. [PubMed: 17939996]

68. Tyler KL, et al. CSF findings in 250 patients with serologically confirmed West Nile virus meningitis and encephalitis. Neurology 2006;66(3):361-5. [PubMed: 16382032]

69. Petropoulou KA, et al. West Nile virus meningoencephalitis: MR imaging findings. AJNR Am J Neuroradiol 2005;26(8):1986-95. [PubMed: 16155147]

70. Ali M, et al. West Nile virus infection: MR imaging findings in the nervous system. AJNR Am J Neuroradiol 2005;26(2):289-97. [PubMed: 15709126]

71. Rossi SL, et al. Adaptation of West Nile virus replicons to cells in culture and use of replicon-bearing cells to probe antiviral action. Virology 2005;331(2):457-70. [PubMed: 15629788]

72. Anderson J, Rahal JJ. Efficacy of interferon alpha- $2 b$ and ribavirin against West Nile virus in vitro. Emerg Infect Dis 2002;8(1):107-8. [PubMed: 11749765]

73. Chan-Tack KM, Forrest G. Failure of interferon alpha-2b in a patient with West Nile virus meningoencephalitis and acute flaccid paralysis. Scand J Infect Dis 2005;37(11-12):944-6. [PubMed: 16308241]

74. Chowers MY, et al. Clinical characteristics of the West Nile fever outbreak, Israel, 2000. Emerg Infect Dis 2001;7(4):675-8. [PubMed: 11585531]

75. Kalil AC, et al. Use of interferon-alpha in patients with West Nile encephalitis: report of 2 cases. Clin Infect Dis 2005;40(5):764-6. [PubMed: 15714427]

76. Sayao AL, et al. Calgary experience with West Nile virus neurological syndrome during the late summer of 2003. Can J Neurol Sci 2004;31(2):194-203. [PubMed: 15198443]

77. Weiss D, et al. Clinical findings of West Nile virus infection in hospitalized patients, New York and New Jersey, 2000. Emerg Infect Dis 2001;7(4):654-8. [PubMed: 11589170] 
78. Morrey JD, et al. Efficacy of orally administered T-705 pyrazine analog on lethal West Nile virus infection in rodents. Antiviral Res 2008;80(3):377-9. [PubMed: 18762216]

79. Ben-Nathan D, et al. Using high titer West Nile intravenous immunoglobulin from selected Israeli donors for treatment of West Nile virus infection. BMC Infect Dis 2009;9:18. [PubMed: 19222853]

80. Saquib R, et al. West Nile virus encephalitis in a renal transplant recipient: the role of intravenous immunoglobulin. Am J Kidney Dis 2008;52(5):e19-21. [PubMed: 18676077]

81. Sejvar JJ. The long-term outcomes of human West Nile virus infection. Clin Infect Dis 2007;44(12): 1617-24. [PubMed: 17516407]

82. Pogodina VV, et al. Study on West Nile virus persistence in monkeys. Arch Virol 1983;75(1-2):7186. [PubMed: 6299247]

83. Siddharthan V, et al. Persistent West Nile virus associated with a neurological sequela in hamsters identified by motor unit number estimation. J Virol 2009;83(9):4251-61. [PubMed: 19224990]

84. Penn RG, et al. Persistent neuroinvasive West Nile virus infection in an immunocompromised patient. Clin Infect Dis 2006;42(5):680-3. [PubMed: 16447115]

85. Brenner W, et al. West Nile Virus encephalopathy in an allogeneic stem cell transplant recipient: use of quantitative PCR for diagnosis and assessment of viral clearance. Bone Marrow Transplant 2005;36(4):369-70. [PubMed: 15968282]

86. Kapoor H, et al. Persistence of West Nile Virus (WNV) IgM antibodies in cerebrospinal fluid from patients with CNS disease. J Clin Virol 2004;31(4):289-91. [PubMed: 15494271]

87. Prince HE, et al. Persistence of West Nile virus-specific antibodies in viremic blood donors. Clin Vaccine Immunol 2007;14(9):1228-30. [PubMed: 17652525]

88. Roehrig JT, et al. Persistence of virus-reactive serum immunoglobulin m antibody in confirmed west nile virus encephalitis cases. Emerg Infect Dis 2003;9(3):376-9. [PubMed: 12643836]

89. Rossi SL, et al. Mutations in West Nile virus nonstructural proteins that facilitate replicon persistence in vitro attenuate virus replication in vitro and in vivo. Virology 2007;364(1):184-95. [PubMed: 17382364]

90. Keller BC, et al. Resistance to alpha/beta interferon is a determinant of West Nile virus replication fitness and virulence. J Virol 2006;80(19):9424-34. [PubMed: 16973548]

91. Shrestha B, Diamond MS. Role of CD8+ T cells in control of West Nile virus infection. J Virol 2004;78(15):8312-21. [PubMed: 15254203]

92. Shrestha B, Samuel MA, Diamond MS. CD8+ T cells require perforin to clear West Nile virus from infected neurons. J Virol 2006;80(1):119-29. [PubMed: 16352536]

93. Shrestha B, et al. Gamma interferon plays a crucial early antiviral role in protection against West Nile virus infection. J Virol 2006;80(11):5338-48. [PubMed: 16699014]

94. Sitati EM, Diamond MS. CD4+ T-cell responses are required for clearance of West Nile virus from the central nervous system. J Virol 2006;80(24):12060-9. [PubMed: 17035323]

95. Wang T, et al. IFN-gamma-producing gamma delta T cells help control murine West Nile virus infection. J Immunol 2003;171(5):2524-31. [PubMed: 12928402]

96. Wang Y, et al. CD8+ T cells mediate recovery and immunopathology in West Nile virus encephalitis. J Virol 2003;77(24):13323-34. [PubMed: 14645588]

97. Diamond MS, et al. B cells and antibody play critical roles in the immediate defense of disseminated infection by West Nile encephalitis virus. J Virol 2003;77(4):2578-86. [PubMed: 12551996]

98. Klein RS, et al. Neuronal CXCL10 directs CD8+ T-cell recruitment and control of West Nile virus encephalitis. J Virol 2005;79(17):11457-66. [PubMed: 16103196]

99. Purtha WE, et al. Early B-cell activation after West Nile virus infection requires alpha/beta interferon but not antigen receptor signaling. J Virol 2008;82(22):10964-74. [PubMed: 18786989]

100. Diamond MS, et al. A critical role for induced IgM in the protection against West Nile virus infection. J Exp Med 2003;198(12):1853-62. [PubMed: 14662909]

101. Ng T, et al. Equine vaccine for West Nile virus. Dev Biol (Basel) 2003;114:221-7. [PubMed: 14677692]

102. Samina I, et al. An inactivated West Nile virus vaccine for domestic geese-efficacy study and a summary of 4 years of field application. Vaccine 2005;23(41):4955-8. [PubMed: 16023273] 
103. Arroyo J, et al. ChimeriVax-West Nile virus live-attenuated vaccine: preclinical evaluation of safety, immunogenicity, and efficacy. J Virol 2004;78(22):12497-507. [PubMed: 15507637]

104. Minke JM, et al. Recombinant canarypoxvirus vaccine carrying the prM/E genes of West Nile virus protects horses against a West Nile virus-mosquito challenge. Arch Virol Suppl 2004;(18):221-30. [PubMed: 15119777]

105. Monath TP, et al. A live, attenuated recombinant West Nile virus vaccine. Proc Natl Acad Sci U S A 2006;103(17):6694-9. [PubMed: 16617103]

106. Pletnev AG, et al. Molecularly engineered live-attenuated chimeric West Nile/dengue virus vaccines protect rhesus monkeys from West Nile virus. Virology 2003;314(1):190-5. [PubMed: 14517072]

107. Davis BS, et al. West Nile virus recombinant DNA vaccine protects mouse and horse from virus challenge and expresses in vitro a noninfectious recombinant antigen that can be used in enzymelinked immunosorbent assays. J Virol 2001;75(9):4040-7. [PubMed: 11287553]

108. Chu JH, Chiang CC, Ng ML. Immunization of flavivirus West Nile recombinant envelope domain III protein induced specific immune response and protection against West Nile virus infection. J Immunol 2007;178(5):2699-705. [PubMed: 17312111]

109. Ledizet M, et al. A recombinant envelope protein vaccine against West Nile virus. Vaccine 2005;23 (30):3915-24. [PubMed: 15917113]

110. Lieberman MM, et al. Preparation and immunogenic properties of a recombinant West Nile subunit vaccine. Vaccine 2007;25(3):414-23. [PubMed: 16996661]

111. Qiao M, et al. Induction of sterilizing immunity against West Nile Virus (WNV), by immunization with WNV-like particles produced in insect cells. J Infect Dis 2004;190(12):2104-8. [PubMed: 15551208]

112. Seino KK, et al. Comparative efficacies of three commercially available vaccines against West Nile Virus (WNV) in a short-duration challenge trial involving an equine WNV encephalitis model. Clin Vaccine Immunol 2007;14(11):1465-71. [PubMed: 17687109] 


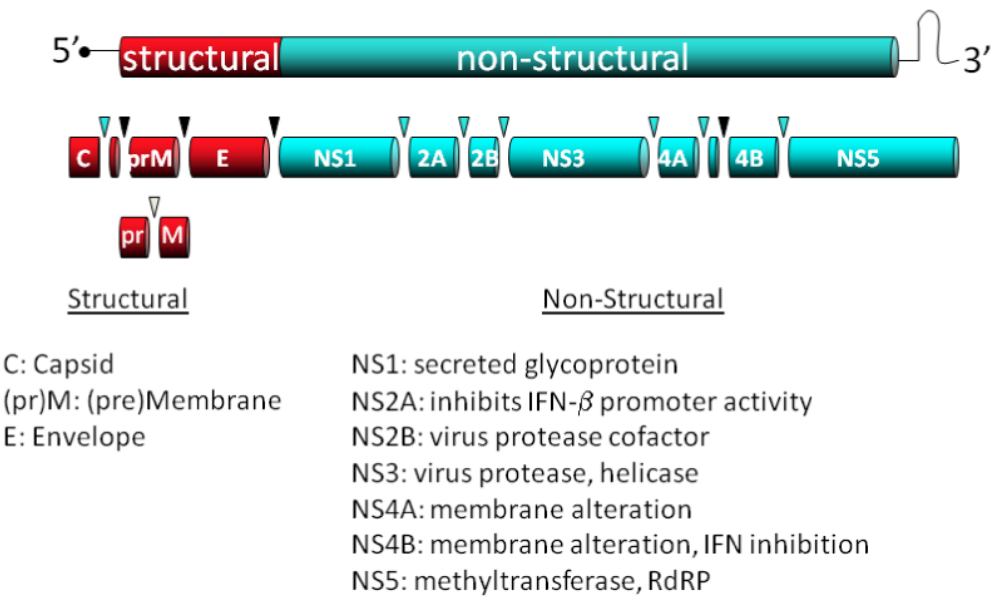

Figure 1. Schematic of WNV genome

A representation of the WNV genome including the 3 structural proteins that make up virion particle and the 7 non-structural proteins necessary for virus replication and immune evasion. 


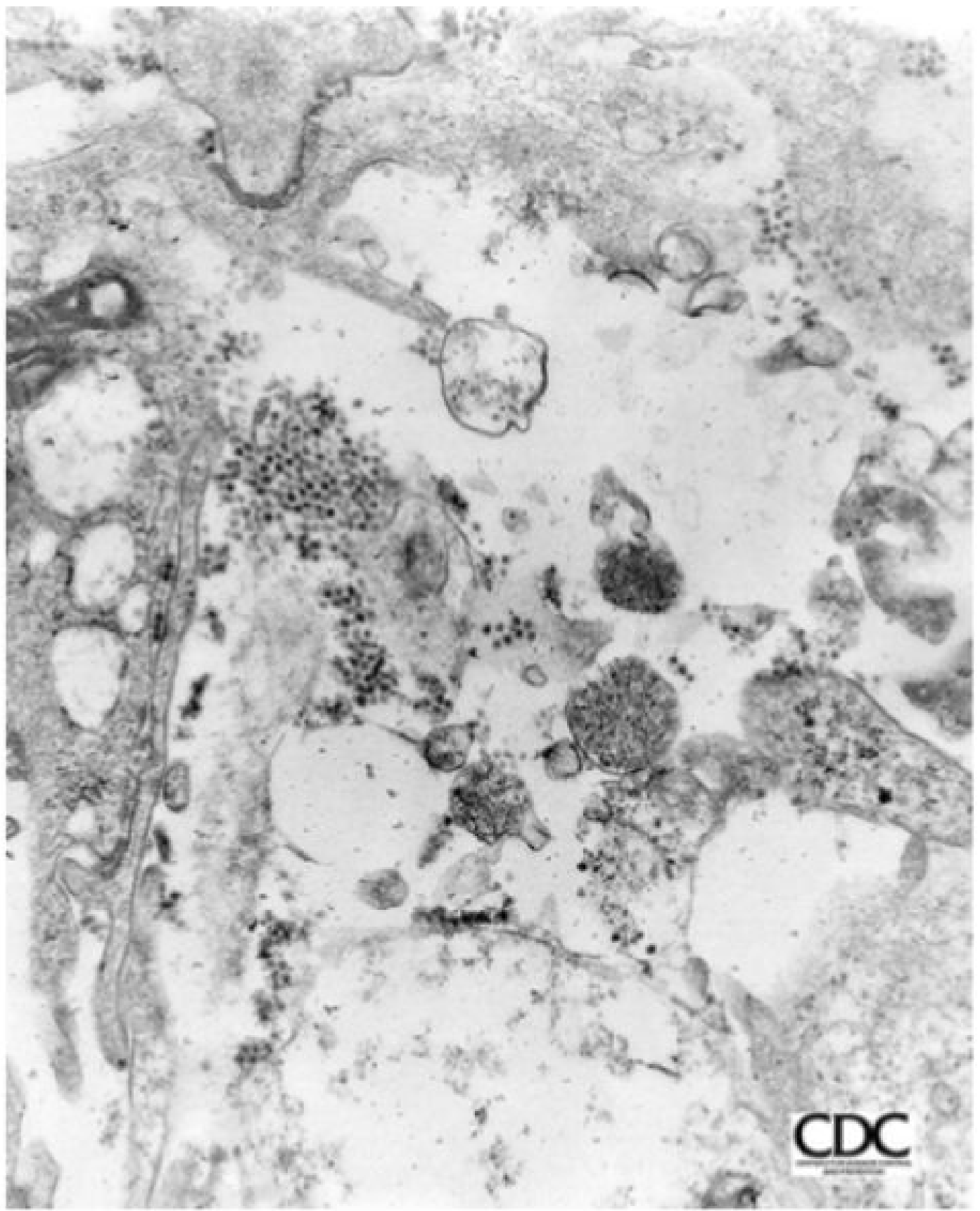

Figure 2. Scanned images are of West Nile virus isolated from brain tissue from an infected crow The tissue was cultured in a Vero cell for a 3-day incubation period. The Vero cells were fixed in glutaraldehyde, dehyrated, placed in an Epon resin, thin sectioned, placed on a copper grid, and stained with uranyl acetate and lead citrate. The grids were then placed in the electron microscope and viewed. Total magnifications, image 65,625x. Image courtesy of CDC (Bruce Cropp, Microbiologist, Division of Vector-Borne Infectious Diseases). 


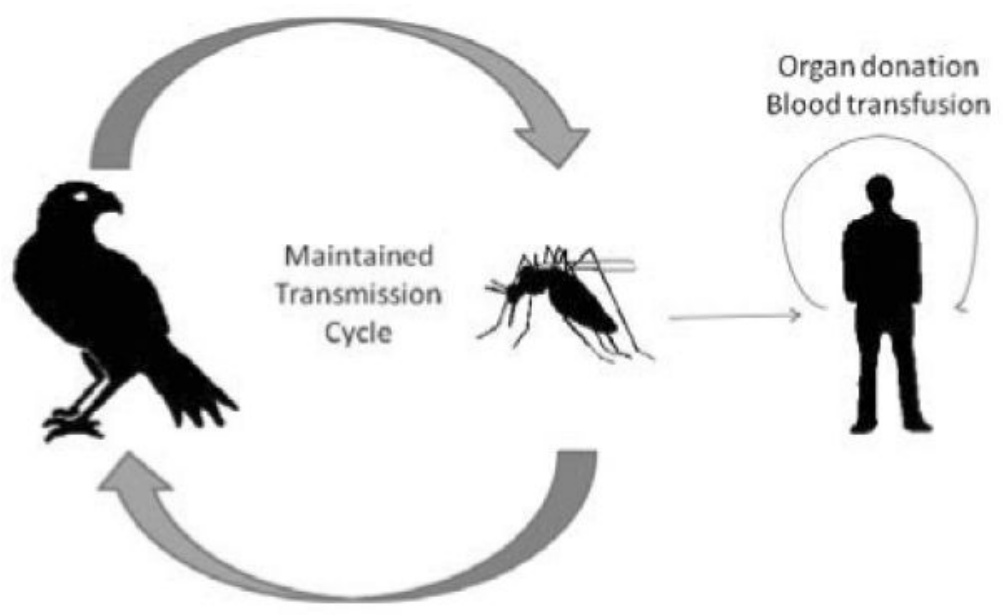

Figure 3. Diagram of the WNV transmission cycle

The maintenance of WNV in nature depends upon many avian and mosquito species. Humans and other incidental hosts (like horses) become infected when WNV-infected mosquito takes a bloodmeal from them. 


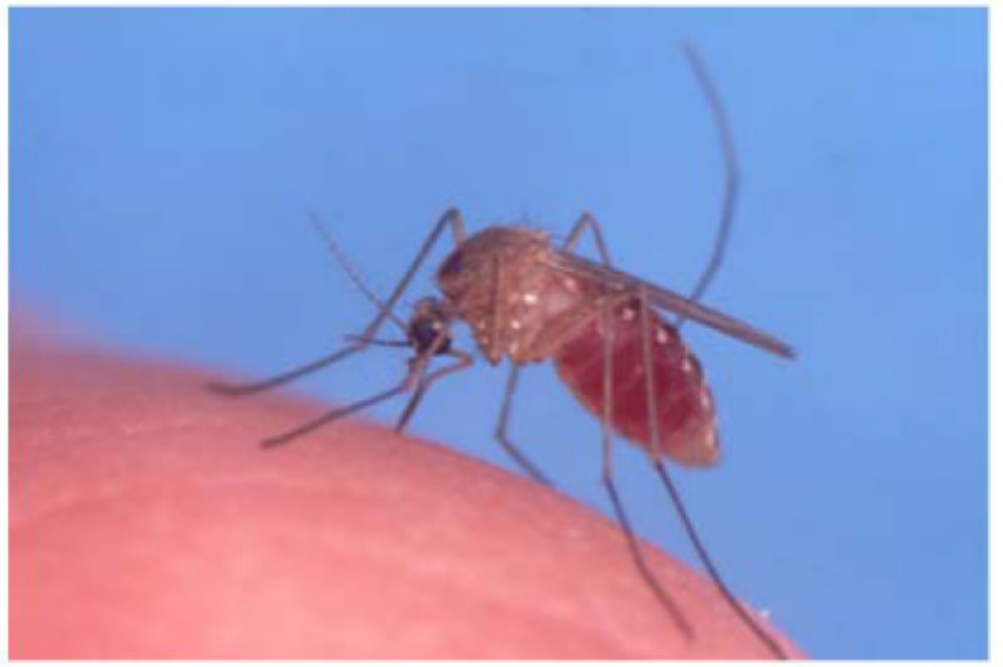

Figure 4. Culex mosquito

The Culex species of mosquito is the most common vector of WNV. Photograph of Culex species mosquito feeding. Courtesy of USGS. 


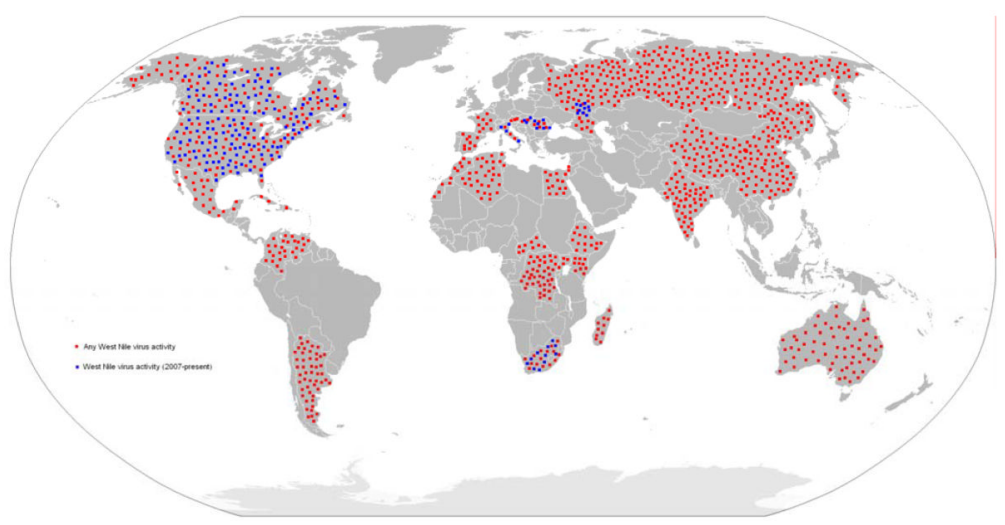

Figure 5. Distribution of WNV

Countries with historic or recent (2007-present) WNV activity (isolations from mosquitoes, birds, horses or humans) are highlighted in red and blue, respectively. 


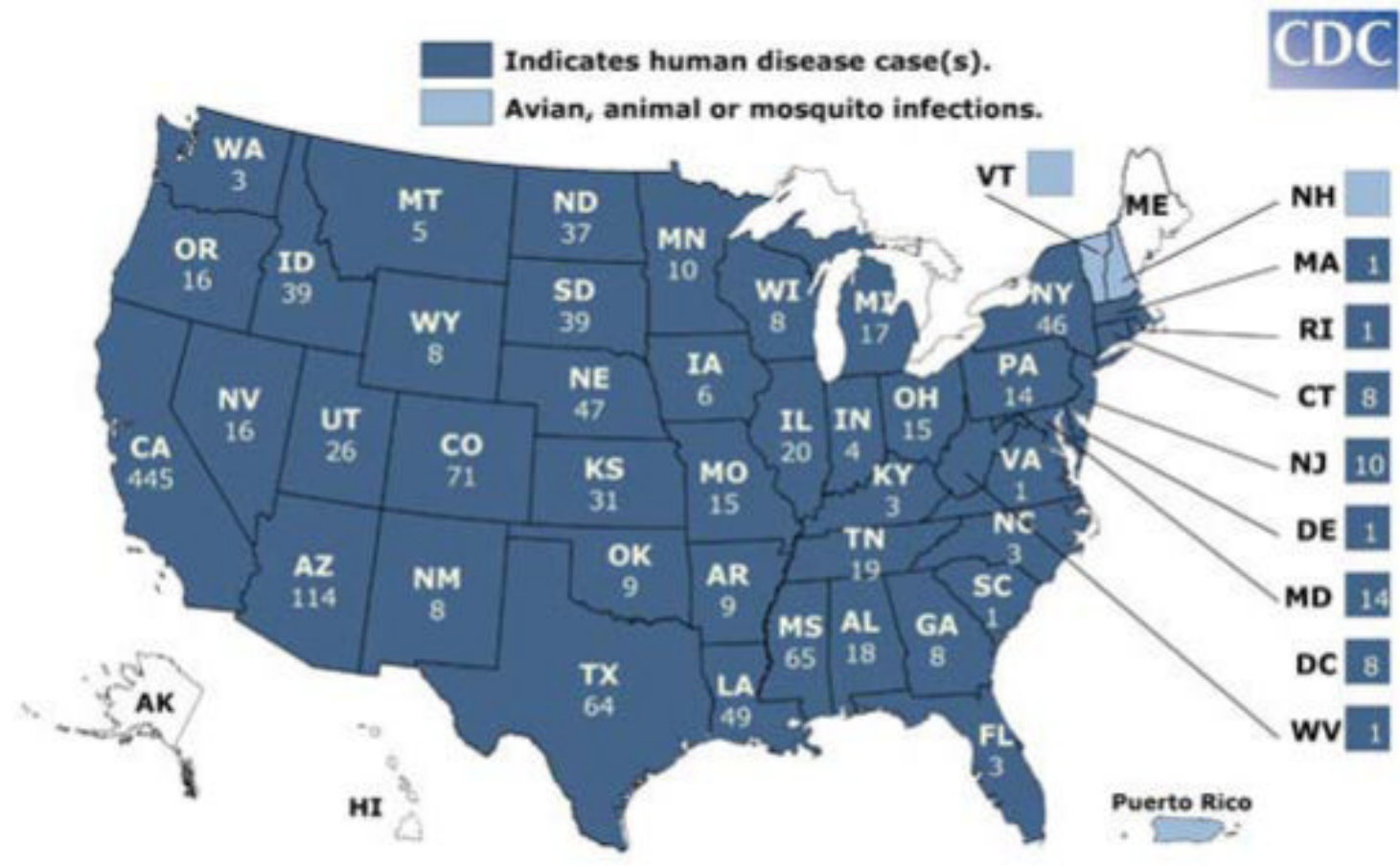

http://www.cdc.gov/ncidod/dvbid/westnile/Mapsactivity/surv\&control08Maps_PrinterFriendly.htm

Figure 6.

The number of confirmed human cases of WNV disease in the United States in 2008. Courtesy of CDC. 

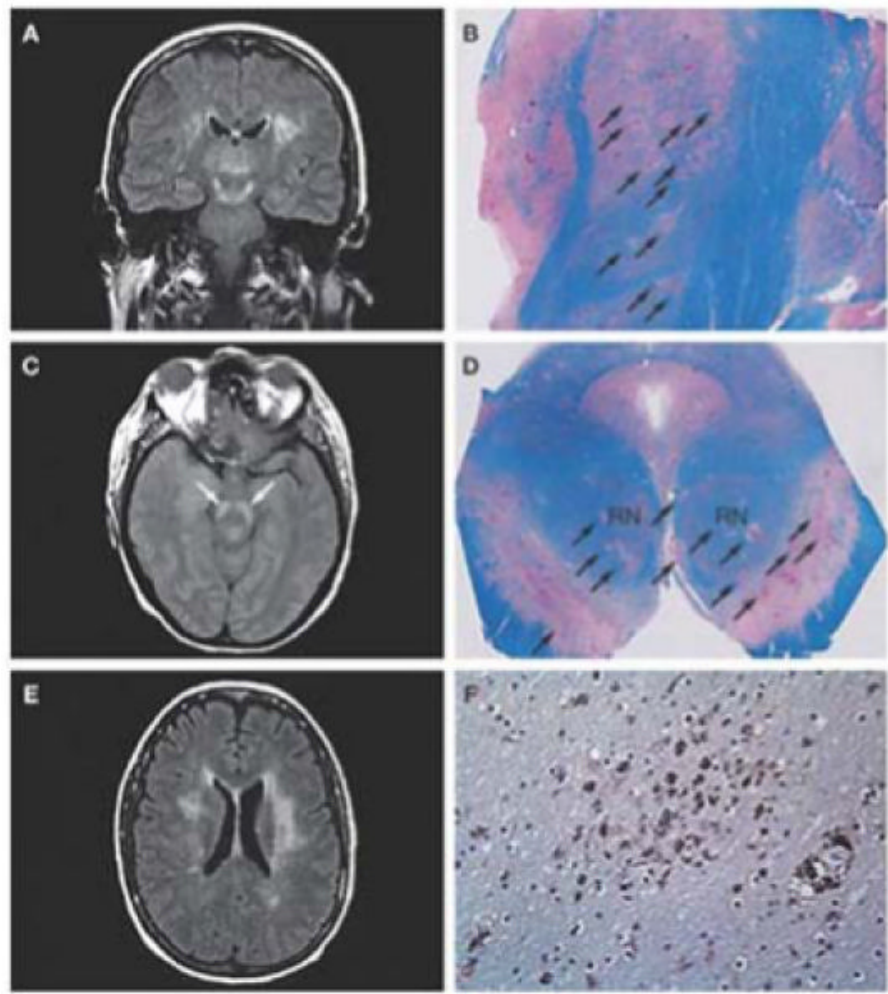

Figure 7. Radiographic and neuropathologic findings in West Nile virus encephalitis

(A) Coronal fluid-attenuated inversion recovery (FLAIR) magnetic resonance image shows an area of abnormally increased signal in the thalami, substantia nigra (extending superiorly toward the subthalamic nuclei) and white matter. (B) Corresponding tissue section from the same patient at autopsy 15 days later, stained with Luxol fast blue-periodic acid Schiff for myelin, shows numerous ovoid foci of necrosis and pallor throughout the thalamus and subthalamic nucleus (arrows). (C) Axial proton density image at the level of the midbrain shows a bilaterally increased signal in the substantia nigra (arrows). (D) Corresponding tissue section at autopsy, stained with Luxol fast blue-periodic acid Schiff, illustrates multifocal involvement of the substantia nigra (arrows), with nearly 50\% of the area destroyed; the red nuclei are clearly affected. (E) Axial FLAIR image at the level of the lateral ventricle bodies shows a bilaterally increased signal within the white matter. A scan performed approximately 5 months earlier demonstrated an abnormal signal in the left periventricular white matter. This signal increased once West Nile virus encephalitis developed, and the lesions in the right cerebral white matter (left side of photograph) were new. (F) Photomicrograph taken from the right periventricular white matter, immunostained with the HAM56 antibody, shows numerous macrophages, both in perivascular areas (lower right) and diffusely throughout the white matter (center). Permission: Kleinschmidt-DeMaster BK et al. (2004). Arch Neurology 61:

1210-1220. 


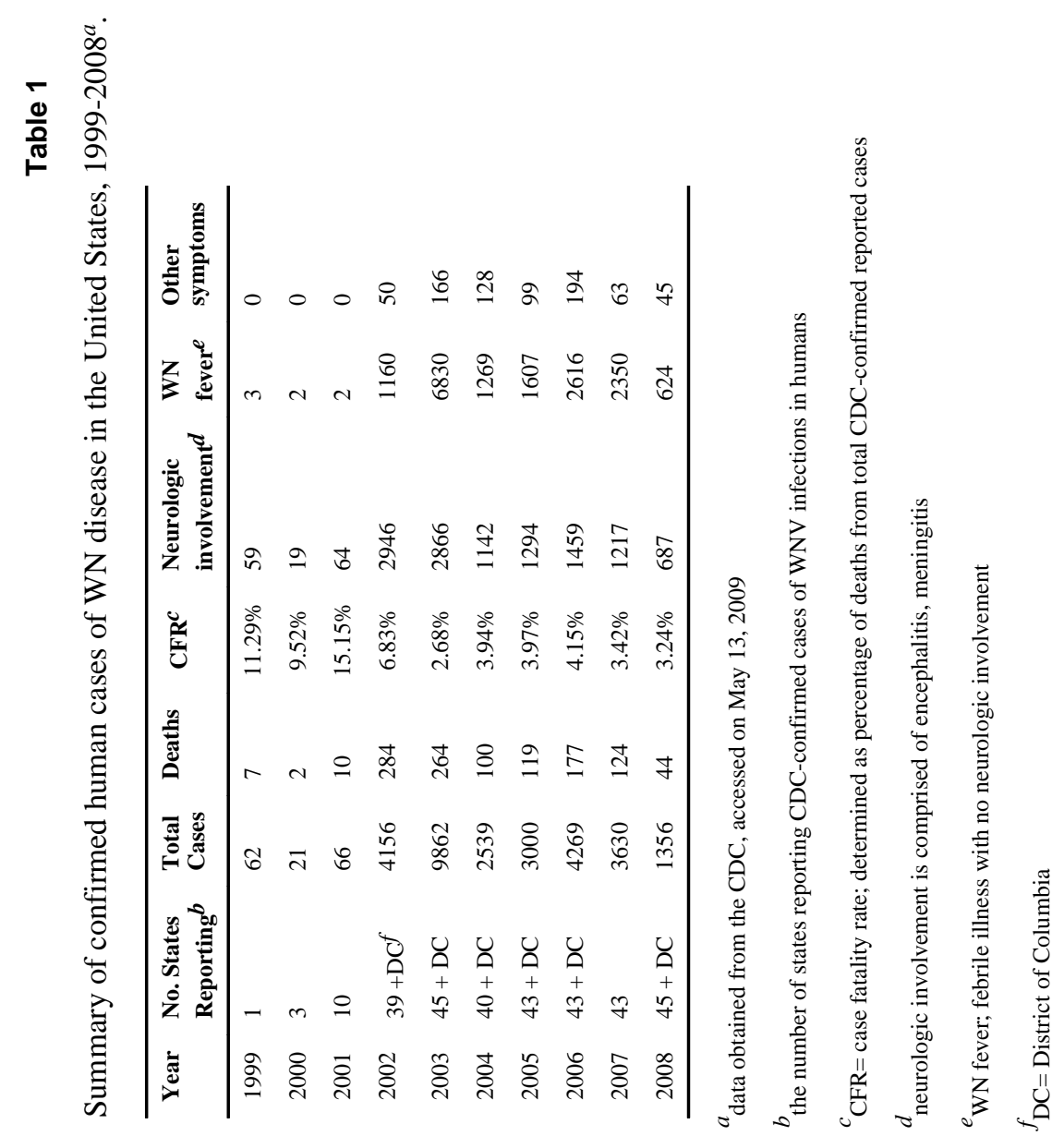

Clin Lab Med. Author manuscript; available in PMC 2011 March 1. 
TnQTable 2

\section{Laboratory Tests and Diagnosis of WNV Infection}

\begin{tabular}{|c|c|}
\hline Test & $\underline{\text { Positive Results }}$ \\
\hline CBC & Anemia, lymphopenia, thrombocytopenia \\
\hline IgM-specific ELISA & WNV-specific IgM antibodies detected \\
\hline PRNT & $\begin{array}{l}\text { Known virus stock growth inhibited in tissue culture by serum, } \\
\text { indicating neutralizing antibodies }\end{array}$ \\
\hline NAT & PCR amplification shows presence of WNV genome RNA \\
\hline $\begin{array}{l}\text { Virus isolation/Plaque } \\
\text { assay }\end{array}$ & Serum or CSF contain virus as seen in plaque assay \\
\hline CSF analysis & $\begin{array}{l}\text { Antibodies and/or virus present by ELISA or plaque assay, } \\
\text { Elevated protein and increased polymorphonuclear cells, } \\
\text { Negative gram stain }\end{array}$ \\
\hline EMG/NCS & Severe effects on anterior horn cells \\
\hline
\end{tabular}

Clin Lab Med. Author manuscript; available in PMC 2011 March 1. 


\section{Table 3}

\section{WNV vaccines}

A partial list of licensed and preclinical vaccines against WNV.

\begin{tabular}{|c|c|c|c|}
\hline Type & Antigen & Sponsor & Stage of Development \\
\hline \multicolumn{4}{|l|}{ Chimeric (vector) } \\
\hline Recombitek TM (canarypox) & WNV-prM-E & Merial & Licensed for horses \\
\hline Chimerivax ${ }^{\mathrm{TM}}$ (yellow fever virus) & WNV-prM-E & Acambis & Phase II \\
\hline WNV-DENV4 (dengue virus 4) & WNV-prM-E & NIAID/NIH & Phase II \\
\hline \multicolumn{4}{|l|}{ DNA } \\
\hline WNV-DIII & WNV-DIII & Multiple labs & Preclinical \\
\hline WNV-E & WNV-E & Multiple labs & Preclinical \\
\hline WNV-prM-E & WNV-prM-E & Multiple labs & Preclinical \\
\hline \multicolumn{4}{|l|}{ Inactivated/Killed } \\
\hline Innovator $\mathrm{TM}$ & Whole virus & Fort Dodge Animal Health & Licensed for horses \\
\hline \multicolumn{4}{|l|}{ Subvirion Particles/Virus-like Particles } \\
\hline WNV-prM-E & WNV-prM-E & Multiple labs & preclinical \\
\hline
\end{tabular}

Sources: www.fortdodgelivestock.com, www.merial.com, www.intervetusa.com, www.clinicaltrials.gov 